\title{
'n Ondersoek na die aanwending van musiek as hulpmiddel in pastorale terapie binne 'n gespreksmodel
}

\author{
J F Maritz \& T F J Dreyer ${ }^{1}$ \\ Departement Praktiese Teologie \\ Universiteit van Pretoria
}

\begin{abstract}
The use of music in pastoral therapy within the structure of a model of discourse

This is part two of an article on the use of music in pastoral therapy. The first part of the article dealt with theoretical issues, while the second part explores the practical possibilities of the counterpoint between music and pastoral therapy. It is argued that the model of conversation could be a possible structure to accommodate this holistic approach. The aim of this exploration is to deal with and help a person in need as a whole, as an integrated being. Pastoral therapy is an opportunity for people to realise their creative possibilities and responsibilities to lead a life of hope and praise before God. The structured use of music could enhance and enrich this opportunity.
\end{abstract}

\section{INLEIDING}

Die verbinding tussen musiek en pastoraat mag op die eerste oogopslag dalk minder bekend voorkom as die meer gevestigde verbinding tussen musiek en liturgie. Die grondvoorbeeld van hierdie verbinding tussen musiek en pastoraat kom egter in die Bybel

\footnotetext{
1 Die artikel is die tweede verwerking van J F Maritz se MA Teologie-skripsie in die Departement Praktiese Teologie, met as studieleier prof dr T F J Dreyer, hoof van die Hervormde Teologiese Kollege, Fakulteit Teologie, Universiteit van Pretoria.
} 
voor in 1 Samuel 16:14-23. Die jong skaapwagter, Dawid, bring met sy harpmusiek telkens verandering in die gemoed van Saul.

In 'n poging om die verbinding tussen musiek en pastoraat in 'n na-moderne era uiteen te sit - en dit so prakties moontlik te doen - moet dit myns insiens binne 'n gespreksmodel gedoen word. Die doel van hierdie studie is nie om empiriesgeverifieerde resultate te verskaf nie. Dit is hoogstens om die moontlikheid van die verbinding tussen musiek en pastoraat te ondersoek. Die idee is om 'n sensitiwiteit en openheid tot die moontlikheid vir die gebruik van musiek in die pastoraat te kommunikeer.

\section{MUSIEK EN PASTORALE TERAPIE BINNE 'N GESPREKS- MODEL}

Louw (1997:304) poog om met 'n gespreksmodel vir pastorale terapie die teorie (pastorale teologie) en praxis (pastorale antropologie) te integreer, "met die oog op 'n praktykmodel waarbinne die vraagstuk na 'n metode vir effektiewe kommunikasie van die heil aan die orde gestel word." Die fasemodel wat Louw voorstel, weerspieël sy aanname dat die affektiewe, kognitiewe, konatiewe en normatiewe dimensies 'n deurslaggewende rol in mense se gedrag speel. Louw (1997:305) beklemtoon dat die fases siklies en as 'n vervlegde spiraal gesien moet word, en nie as liniêre opeenvolging in tyd nie. Wanneer ek musiek dus binne hierdie model voorstel, is dit met hierdie voorbehoud in gedagte. Juis omdat musiek, soos geloof, die mens op al hierdie vlakke gelyktydig aanspreek, is dit 'n uitstekende medium om van gebruik te maak binne 'n pastorale ontmoeting.

Daar is ook 'n ander belangrike voorbehoud ter sprake. Soos reeds betoog, dra die teologiese teorie ' $n$ bepaalde gewig in die pastorale ontmoetingsgebeure. Die aanspraak van die Skrif bly die belangrikste gesag en die imperatief moet saam met die indikatief en beloftes van die kerugma aan die persoon in nood oorgedra word. Wanneer ek nou musiek bytrek as moontlike hulpmiddel, is dit met hierdie voorbehoud in gedagte. Louw bespreek die totale teologiese teorie en gebruik van geloofsbronne binne die gesprek in sy boek Pastorale ontmoeting en vertolking, daarom kom dit glad nie hier aan die orde nie. 
'n Laaste belangrike opmerking is hier nodig. Dit is belangrik om te onderskei tussen musiekterapie en musiek as hulpmiddel in terapie. Van Schalkwyk (1998:24) wys op die belangrike onderskeid tussen musiek in terapie en musiek as terapie. Musiek in terapie impliseer dat musiek nie as primêre terapeutiese agent beskou word nie, maar bloot as hulpmiddel of ondersteuning van terapeutiese prosesse. Die funksie van musiek word dan gesien om die kliënt voor te berei of toeganklik te maak vir die werklike intervensiestrategie. Hierteenoor word musiek as terapie beskryf ten opsigte van die sentrale posisie wat musiek in die terapeutiese proses inneem. In die geval van musiekterapie (wat die gespesialiseerde vorm van musiek as terapie is), is musiek self die stimulus wat verandering in die kliënt se gedrag bewerkstellig. 'n Verdere onderskeid is dat musiek in terapie op nie-musikale response fokus wat die kliënt ondersteun tydens die terapeutiese proses. Daarteenoor veronderstel musiekterapie aktiewe musikale deelname van die kliënt aan een of ander musiekaktiwiteit. Waar musiekterapie dus hoofsaaklik van lewendige musiek (byvoorbeeld speel van 'n instrument) gebruik maak, sal musiek wat in terapie gebruik word van voorafopgeneemde musiek gebruik maak.

In hierdie studie stel ek dus belang in die rol wat musiek in terapie kan speel (in hierdie geval pastorale terapie), waar geloof en die geloofsbronne die primêre metode van intervensie is. Die klem val dus op pastorale terapie, met musiek as hulpmiddel, as bykomende perspektief.

\subsection{Fase 1: Kontakbou}

In hierdie eerste fase ontmoet die pastor en pastorant. Tydens die eerste ontmoeting is die bou van 'n vertrouensverhouding veral belangrik. Parsons (1985:99) meen dat die indrukke wat die pastorant in hierdie stadium vorm, deurslaggewend is vir die uitkomste van die ontmoeting. "It is these positive expectations which will not only provide the client with a sense of hope and desire for continuation, but in fact may play the essential role to the therapeutic movement. The arousal of 'hope' and positive expectations may be at the core of therapeutic change." Hierdie eerste indrukke gaan gepaard met 'n groet,

die atmosfeer van die vertrek, wedersydse aanvaarding en vertroue en 'n gewaarwording van die pastorant dat die pastor in sy of haar probleme belangstel. Die pastorant sal (of 
daar ' $\mathrm{n}$ reeds bestaande relasie tussen hom/haar en die pastor is of nie) angstig en gespanne wees oor die gesprek wat voorlê.

Musiek kan 'n onskatbare bydrae lewer tot die kontakboufase. Agtergrondmusiek in die ontvangskamer kan die aanvanklike angstigheid van die persoon kalmeer. Dit is moontlik dat musiek die eerste groet en ontvangs kan versag omdat die persoon se emosies en indrukke deur die musiek georden en gestruktureer word. 'n Persoon wat glad nie ingestel is op musiek nie, sal moontlik nie eers bewus wees dat musiek speel nie, maar dit kan steeds 'n kalmerende invloed hê. Dit kan 'n vertrek warm en vriendeliker laat voorkom. Vir 'n persoon wat dit wel onmiddellik opmerk, kan musiek 'n veilige en vertroostende omgewing voorstel. Vir my as terapeut is musiek 'n hulpmiddel om my gemaklik en veilig te laat voel sodat ek met openheid die ander persoon kan ontmoet. Daar is die afgelope 60 jaar baie navorsing gedoen oor die effek van verskillende tipes agtergrondmusiek op verskillende tipes mense (kyk bv Jannasch 1995:39).

Musiek kan in die eerste deel van die gesprek ook as verbale aanknopingspunt dien. Die pastorant kan moontlik 'n opmerking maak oor die musiek. Die pastor kan aan die pastorant vra na watter tipe musiek sy/hy graag luister of op watter wyse hul musiek in hul lewe gebruik, hoe die persoon deur musiek beïnvloed word. Dit kan reeds aan die pastor bepaalde inligting verskaf oor die agtergrond, omstandighede en volwassenheid van die pastorant. Ek meen byvoorbeeld dat 'n tiener wat onwillig is om te begin kommunikeer hierdie onderwerp as nie-bedreigend sal ervaar en graag 'n mening sal lug. Van daaruit kan die gesprek gelei word na musiek in die huis, wat lei na verhouding met ouers.

Musiek kan ook in hierdie fase gebruik word om die persoon bewus te maak van verskillende emosies wat ervaar word. Dit kan 'n medium wees om emosies spesifiek te verwoord en te onderskei. Musiek kan ook die belangrike funksie hê dat pastor en pastorant bepaalde emosies deel, wat die moontlikheid van saam-tot-'n-oplossing kom, versterk. Musiek moet dus hier op 'n baie subtiele wyse aangewend word om die pastorant te kalmeer en 'n vertouensverhouding te sluit sodat daar oorgegaan kan word om oor die probleem te praat. Die musiek moet in hierdie fase sag en op die agtergrond wees. Dit is belangrik dat die musiek van 'n assosiasie-vrye aard moet wees, dit wil sê 
instrumentale musiek wat nie aan 'n verwysende idee gekoppel is nie. Die musiekterm hiervoor is "absolute musiek": musiek wat vry is van buite-musikale implikasies en 'n spesifieke emosionele karakter (Harvard 1983:2). Jannasch (1995:35) gee spesifieke voorbeelde van musiek vir hierdie doel.

\subsection{Fase 2: Probleemanalise}

In hierdie fase word die probleem geanaliseer. Die terapeut se rol is spesifiek om die persoon te help om gegewens te integreer en logiese gevolgtrekkings te maak (Louw 1997:417). Die pastor ondersoek dus saam met die terapeut en reflekteer voortdurend sy/haar eie verstaan. Die pastor moet hier aktief luister en die ander persoon oriënteer ten opsigte van perspektiefbou en persepsieverandering. Dit is belangrik dat die pastorant sonder hindernisse oor die probleem praat. "One way in which the councelor can encourage and facilitate such disclosure is through his or her employment of proper attending and questioning skills" (Parsons 1985:106). Alhoewel daar verskeie tegnieke en metodes is waarvolgens die pastor maksimum kommunikasie, empatie en aktiewe luister kan fasiliteer, is die terapeut soms tog verleë indien die gespreksgenoot nie bereid is om werklik eerlik en openlik oor die probleem te praat nie.

Musiek kan funksioneel aangewend word om van hierdie probleme te oorbrug. Dit is moontlik dat die strukturele aspek van musiek die kognitiewe proses kan ondersteun. Saam met die onbewustelike beluistering van musiek (waarin musiekstrukture gevorm word deur motiewe wat ontwikkeling, spanning en oplossing insluit) kan die persoon tot 'n beter verstaan en uiteensetting van die probleem kom. (Hierdie kenmerk van musiek is in deel een van hierdie artikel onder hoofstuk vyf bespreek.) Musiek, wat per definisie geordende klank is, kan meehelp om orde in 'n persoon se verwarde denke te bring. Musiek, wat uit verskillende parameters bestaan (ritme, melodie, harmonie) en gelyktydig op al hierdie vlakke besig is om motiewe te ontwikkel, deur prosesse van spanning en oplossing te gaan, spreek die prosesse in die menslike brein aan. Alhoewel die musiek dus grootliks onbewustelik deur die pastorant ingeneem sal word, is dit moontlik dat dit die gang van die verbale proses kan ondersteun en orden. "The order and structure present in music, especially in its rhythm can help an individual organize his or her own perceptive world" (Peters 1987:51). Daar is heelwat empiriese 
ondersoeke in die verband gedoen en daar bestaan 'n aantal musiekterapie tegnieke (kyk Peters 1987:125-135). Maar musiekterapeute meen dat dit die kommunikatiewe aspek van musiek is wat 'n kernrol in terapie kan speel... "for music may be able to communicate and help establish a relationship where words alone have failed" (Peters 1987:50). Die belangrikste kommunikatiewe aspek van musiek in terapie is dat dit nieverbaal is, dat dit dus 'n hulpmiddel kan word daar waar verbale kommunikasie stol.

Because music is structured reality, something that develops through time and is made up of real physical structures (vibrations) that can be heard, felt and measured, [...] music can be a valuable medium for reestablishing contact with reality for individuals who have withdrawn from reality and society.

(Gaston \& Sears, in Peters 1987:50)

'n Ander kenmerk van musiek wat in hierdie fase gebruik kan word, is in 'n vorige artikel (Maritz \& Dreyer 2001:1282-1283) bespreek. Die het naamlik te doen met die verwysende en introspektiewe funksies van musiek kan in pastorale terapie aangewend word om onverwerkte herinneringe en gevoelens na die oppervlak te bring. "Kennelijk heeft muziek het vermogen een vergeten ervaring en nog niet geheel verwerkt verdriet aan het licht te brengen" (Schelling 1989:83). Don Campbell toon byvoorbeeld aan hoe musiek spesifiek in die rouproses aangewend kan word. "Music helps in the ritual of release, allowing us to let go of our emotions, and to grieve" (Campbell 1997:209).

'n Tegniek uit die musiekterapie wat genoem word GIM (guided imagery and music) sou in die pastoraat baie goed aangewend kon word. "In the GIM procedure, music acts as a catalyst to evoke conscious thoughts and feelings, expanding self-awareness into the upper and lower levels of consciousness. The multidimensional qualities of musical sound allow it to touch many levels of consciousness both simultaneously or in sequence" (Bonny \& Savary, in Peters 1987:30). Louw (1997:374) bespreek geloofsevaluering ('n geloofsanalise, religieuse analise en analise van die pastorant se Godsvoorstellings) as belangrike stap tydens hierdie fase van die pastorale gesprek. Dit sou moontlik wees vir die pastor om deur die gebruik van die GIM tegniek so 'n geloofsanalise te maak. Dit impliseer dat die pastor en pastorant saam na spesifiek 
geselekteerde religieuse musiek luister. Deur middel van "roete aanwysings" en vrae kan die pastor belangrike inligting oor die geloofsvolwassenheid, geloofsbeskouing asook Godsvoorstellings van die pastorant kry.

Die voordeel van musiek as hulpmiddel saam met 'n gewoon verbale metode word opgesom in die woorde van Dreikurs (in Jannasch 1995:1):

Using music brought results in cases where other approaches have failed. It seems that the pleasant experience with music, often merely in the background, stimulates participation, permits an increase in the [person's] attention span, and raises his frustration tolerance. External and internal tensions disappear, as reality becomes more pleasant and less threatening. The demands for participation are so subtle that they are not resented or defied.

Hierdie aanhaling raak ' $\mathrm{n}$ ander punt aan wat reeds genoem is, naamlik die gelyke uitnodiging wat musiek aan die deelnemers stel. Hier kan dus nie sprake van dwang of ongelykheid tussen die subjekte wees nie.

Campbell (1997:220 ev) gee spesifieke beluisteringsvoorbeelde en oefeninge vir feitlik elke probleem wat ' $\mathrm{n}$ mens in terapie sal aantref: mishandeling, akute pyn, agressie en anti-sosiale gedrag, Alzheimer en Parkinsons, spanning en stres, outisme, kanker, depressie, leerprobleme en nog vele meer.

Die musiek in hierdie fase sal meer spesifiek en bewustelik as net op die agtergrond wees. Sensitiwiteit, beplanning en voorbereiding sal nodig wees om musiek hier funksioneel, doelmatig en relevant tot die persoon en die probleem aan te wend.

\subsection{Fase 3: Doelwitformulering}

Nadat die terapeut aan die einde van fase 2 'n uiteensetting gegee het en daar konsensus tussen die gespreksgenote bewerkstellig is, word daar oorbeweeg na 'n fase van besluitneming en doelwitformulering. In al die stappe wat Louw (1997:418) in hierdie fase voorstel, naamlik probleemomskrywing, bronanalise, kontraksluiting, doelwitformulering, tuiswerkopdragte, prioriteitsbepaling en programontwikkeling, kan die 
terapeut 'n holistiese benadering ten opsigte van die kunste en spesifiek musiek volg. Hier volg 'n aantal moontlikhede:

- Die pastor behoort van simboliese en metaforiese taal gebruik te maak. Die pastor kan die visie van die pastorant verbreed deur beelde uit die kunste, poësie en natuur in analogie met die probleem te gebruik. Die pastorant moet ook aangemoedig word om die probleem in beelde te dink en te visualiseer. Die pastor kan die vaslegging van rituele en simbole in die lewe van die gesin aanmoedig. Musiek kan gebruik word om byvoorbeeld 'n ritueel rondom 'n verjaarsdag, Sondae, kerklike feesdae soos Paasfees en Kersfees te vestig. So 'n ritueel (en spesifiek musiek wat met die ritueel verbind word) kan later vir 'n persoon in nood 'n vaste orientasiepunt word wanneer musiek die verlede terugroep.

- Estetiese bewuswording verhoog lewenskwaliteit. Die pastorant kan aangemoedig word om die leemte wat ontstaan het deur die aflegging van 'n disfunksionerende gewoonte met spesifieke estetiese doelwitte te vul. As deel van doelwitformulering kan mense dus gelei word om musiek, poësie en ander kunste struktureel in hulle lewe te inkorporeer.

- $\quad$ Dit is veral by die punt van Louw (1997:421) oor tuiswerkopdragte waar musiek uitstekend aangewend kan word. 'n Gesin wat saam sing en dans, saam musiek luister, 'n moeder wat vir haar kind sing, is alles wyses wat intimiteit tussen mense kan verhoog en wat nuwe kommunikasiekanale kan open. 'n Persoon wat doelgerig die speel van 'n nuwe instrument aanleer kan eiewaarde verhoog. 'Music can provide a means of self-expression and feelings of self-worth (Sears in Peters 1987:51). Dit word algemeen aanvaar dat die menslike stem die mees geskikte en beskikbare instrument vir heling is. "I tone, therefore I am!" (Campbell 1997:90). 
- Die terapeutiese waarde van die Psalms kan deur die pastor as uitgangspunt gebruik word. 'n Bewussyn van die eeuoue terapeutiese bron wat die Psalms vir gelowiges was, kan nuwe moontlikhede en insigte in die gebruik daarvan vir ' $n$ persoon in nood wees. Psalms kan as poësie gelees word, as liedere gesing word en as gebede gebid word. Dit vervat al die menslike emosies van vreugde, lof en aanbidding tot by smeking, pyn en radeloosheid. Die Psalms kan ook as teologiese bron die imperatief aan die persoon in hierdie fase oordra. Louw (1997:460) toon aan hoedat daar van klag en lyding na lof beweeg kan word deur die korrekte strukturele gebruik van die Psalms in pastorale terapie.

- $\quad$ Musiek bevorder werklike luister. Schelling (1989:82) toon aan hoedat "door de [muziek] de geest en het hart van de mens geopend werden voor het Woord, de openbaring van God. En waar echt gehoor werd, vonden vernieuwing en verandering plaats." Campbell (1997:99) lê ook klem op die belangrike verskil tussen luister en hoor. Luister is 'n aktiewe aksie terwyl hoor passief is. Hy meen dat verkeerd luister of 'n gebrek aan luister grondliggend aan die meeste verhoudingsprobleme is. In pastorale terapie (soos in enige ander terapie) word die vaardigheid van luister beklemtoon. Maar die klem val volgens my hier wyer na mense wat die Woord van God hoor, maar nie luister nie. Dit is moontlik dat musiek in pastorale terapie (soos in die erediens) die funksie kan hê om die Woord (die troos en die vermaning) werklik vir die luisteraar hoorbaar te maak ... om luister te bevorder. "Wie ore het moet luister" (Matt 11:15; my beklemtoning).

- Die terapeutiese waarde van 'n retreat word in die sielkunde hoog aangeslaan. 'n Mens in nood moet kan stil raak, hom of haar onttrek van die alledaagse en die groter prentjie probeer sien. Musiek kan help om te "onttrek" en tot nuwe insigte te kom (kyk Maritz \& Dreyer 2001:1282-1283). In dieselfde asem kan stilte hier net so funksioneel gebruik word. Ons is so gewoond en "verslaaf" aan geluide en geraas om ons. Dit is nodig om mense te lei om stilte te gebruik om God te ontmoet, om in stilte enige selfgesentreerdheid te transendeer. 
- $\quad$ Schelling (1989:80) toon in sy studie oor die terapeutiese waarde van musiek in die Skrif ' $n$ ander belangrike funksie van musiek aan. Nadat bedroefte mense (bv Dawid en Jeremia) hulle klagtes en smart singend en spelend uitgestort het, gaan hulle aan met die daaglikse lewe. Musiek kan as medium vir katarsis funksioneer. Na ontlading deur middel van musiekmaak of musiekbeluistering is dit moontlik om weer aan te gaan met die gesprek, maar ook in die wyer sin in die lewe buite die spreekkamer. Die Psalms en ander Bybelse liedere kan in pastorale terapie hiervoor gebruik word. "Het zingen van deze liederen [Bybelse liedere] geeft het hart gelegenheid zijn gevoelens prijs te geven en te delen met anderen, opdat zijn wonden zullen helen. Die liederen laten ruimte voor de eigen ervaringen, hoe mooi of lelijk die ook zijn" (Schelling 1989:80).

In hierdie fase kan die pastorant dus bewus gemaak word en gelei word om musiek en stilte funksioneel in haar of sy lewe te gebruik. Sonder om te verval in 'n fasemodel meen ek tog dat hierdie fase in wese konatief is. "Met behulp van verantwoordelike besluite wil fase 3 die persoon help om tot doelgerigte gedrag te kom" (Louw 1997:424). Deur musiek en estetiese bewuswording kom die persoon in beweging.

\subsection{Fase 4: Sinontwerp}

Louw praat van hierdie fase as die teleïtiewe fase. Die doelwit van hierdie fase is formulering van die persoon se lewenskwaliteit, deur 'n sinraamwerk en 'n toepassing van sy of haar geloofspotensiaal (Louw 1997:423). Die ontwikkeling van geloofsvolwassenheid tree vir Louw in hierdie fase baie sterk na vore. Vir die doel van hierdie studie word geloofsvolwassenheid omskryf as die persone se bewusword van die kreatiewe vermoë en verantwoordelikheid waaroor hulle beskik om God in hulle totale menswees te loof en te verheerlik. Johansson (1988:12) meen dat mense "...in their fallen state are to be reminded again and again that they do not automatically live creatively. Effort is required." In verantwoordelikheid teenoor die Imago dei het alle mense die vermoë en opgawe om kreatief te reageer teenoor God, mekaar en die Skepping. Kreatief leef beteken om met verbeelding en integriteit op die uitnodiging van God deur Jesus Christus te reageer. Dit beteken om in volheid en in heelheid te reageer. 
Die mens se eenheid lê in die kognitiewe en emosionele, verstand en emosies in wisselwerking. Gebalanseerdheid is die gesonde wisselwerking tussen beide. Die Woord van God spreek beide aan. Musiek spreek ook beide aan. "Religion and music both have an intellectual and emotional side. Both contribute to the Christian faith as a mode of living by being part of the balance needed for holistic living" (Johannson 1988:68).

Gelowiges kan vanuit die pastoraat 'n deelnemende bewussyn ('n lewe tot eer van God wat die totaliteit van menswees en kreatiwiteit omvat) na die erediens terugneem, wat tot verryking van die liturgie en tot opbou van die gemeente van Christus kan wees. Doksologie is ten slotte nie 'n saak alleen tussen 'n mens en God nie, maar moet wyer kring na die gemeenskap van gelowiges. Musiek is by uitstek die medium om ander by hierdie lof aan God in te trek.

Die doelwit wat ek vir pastorale terapie wil beklemtoon is om tot lof te kom. Dit beteken ook om weer onder die indruk van die misterie en die gans-Andersheid van God te kom. Die menslike poging om iets van hierdie God te begryp, is terselfdertyd verwondering, onbegrip en angs. As ons dan sukkel om in woorde hierdie misterie te verwoord, kan musiek help. Musiek poog om verborge dinge oop te maak in die verkenning van tyd en klank. Alle ware kuns wys iets van die misterie en wonder van ons wêreld, wat op sy beurt weer iets bekend maak van die Skepper van díe dinge. Die abstrakte kwaliteit van musiek bevat hierdie moontlikhede. As Johannson in hierdie sin na ware kuns verwys, noem hy die belangrikste kriteria van ware kuns of kuns wat die geloof só kan dien: waarheid, egtheid.

Perhaps remedial measures need to be taken to restore mystery, awe and wonder to their rightful place as context qualities of worship. Surely music cannot do it by itself, but what can be done is to ensure that the music which is needed, helps foster these important characteristics. To call forth awe in a worshipper however, which Walter Nathan suggests is the ground of faith, a work of art must make demands on the hearer. It is not merely literal strangeness or otherworldly association which endows music with transcendental value, but its artistic value, it's true-ness.

(Johannson 1988:100) 
Pastorale terapie is 'n geleentheid om mense bewus te mak van die rol en funksie van musiek om as heel en kreatief outentiek voor God te staan.

\section{GEVOLGTREKKING}

Pastorale terapie is geloofshulp as lewenshulp vanuit 'n perspektief van hoop, met die essensie om te verander en tot verstaan te kom, doksologies gerig. Hierdie studie het gedemonstreer dat die aanwending van musiek in pastorale terapie oor twee funksies beskik. In die eerste plek kan die sensitiewe en kreatiewe gebruik van musiek tydens die terapeutiese proses die persoon in nood ondersteun op nie-verbale wyse. Dit kan meewerk om die probleem te analiseer, om die persoon insig in haar- of homself te gee, om sodoende tot verstaan en verandering te kom. In die tweede plek kan die aanwending van musiek in pastorale terapie die persoon lei tot heelheid en 'n deelnemende bewussyn. Dit kan die ander persoon weer aanmoedig en bewus maak van 'n deelnemende leefwyse met die kreatiewe en skeppende moontlikhede binne haar- of homself, met die estetiese, simboliese en met die natuur. Dit kan die persoon in beweging bring om God in volheid en op kreatiewe wyse te dien en te eer.

\section{Literatuurverwysings}

Apel, W 1983. Harvard Dictionary of Music. 2nd edition. London: Heinemann.

Campbell, D 1997. The Mozart effect: Tapping the power of music to heal the body, strengthen the mind and unlock the creative spirit. New York: Avon Books.

Jannasch, T 1995. Musiek as hulpmiddel in spelterapie. Ongepubliseerde MA-verhandeling (Maatskaplike werk), Universiteit van Pretoria.

Johannson, C M 1988. Music and ministry: A Biblical counterpoint. 2nd edition. Peabody, MA: Hendrickson.

Louw, D J 1997. Pastoraat as ontmoeting en vertolking. Pretoria: Lux Verbi.

Maritz, J F \& Dreyer, T F J 2001. Musiek as hulpmiddel in pastorale terapie. HTS Teologiese Studies 57(3\&4), 1265-1287.

Parsons, R D 1985. The counseling relationship. Clinical handbook of pastoral counseling. New York: Paulist Press. 
Peters, J S 1987. Music therapy: An introduction. Charles C Thomas Publisher.

Schelling, P 1989. Muziek en Kerkewerk. s'Gravenhage: Uitgeverij Boekencentrum BV.

Van Schalkwyk, G J 1998. 'n Sisteemparadigma vir musieksielkunde. Ongepubliseerde Ph D-proefskrif (Sielkunde), Universiteit van Pretoria. 